\title{
Field Evaluation of a Near Zero Energy Home in Oklahoma
}

Conference Paper NREL/CP-550-40875

August 2008

R. Hendron

National Renewable Energy Laboratory

E. Hancock and G. Barker

Mountain Energy Partnership

P. Reeves

Partnership for Resource Conservation

Presented at Energy Sustainability 2007

Long Beach, California

June 27-30, 2007 


\section{NOTICE}

The submitted manuscript has been offered by an employee of the Midwest Research Institute (MRI), a contractor of the US Government under Contract No. DE-AC36-99G010337. Accordingly, the US Government and MRI retain a nonexclusive royalty-free license to publish or reproduce the published form of this contribution, or allow others to do so, for US Government purposes.

This report was prepared as an account of work sponsored by an agency of the United States government. Neither the United States government nor any agency thereof, nor any of their employees, makes any warranty, express or implied, or assumes any legal liability or responsibility for the accuracy, completeness, or usefulness of any information, apparatus, product, or process disclosed, or represents that its use would not infringe privately owned rights. Reference herein to any specific commercial product, process, or service by trade name, trademark, manufacturer, or otherwise does not necessarily constitute or imply its endorsement, recommendation, or favoring by the United States government or any agency thereof. The views and opinions of authors expressed herein do not necessarily state or reflect those of the United States government or any agency thereof.

Available electronically at http://www.osti.gov/bridge

Available for a processing fee to U.S. Department of Energy and its contractors, in paper, from:

U.S. Department of Energy

Office of Scientific and Technical Information

P.O. Box 62

Oak Ridge, TN 37831-0062

phone: 865.576 .8401

fax: 865.576 .5728

email: mailto:reports@adonis.osti.gov

Available for sale to the public, in paper, from:

U.S. Department of Commerce

National Technical Information Service

5285 Port Royal Road

Springfield, VA 22161

phone: 800.553 .6847

fax: 703.605.6900

email: orders@ntis.fedworld.gov

online ordering: http://www.ntis.gov/ordering.htm 


\title{
FIELD EVALUATION OF A NEAR ZERO ENERGY HOME IN OKLAHOMA
}

\author{
Robert Hendron \\ National Renewable Energy Laboratory \\ Golden, CO
}

\author{
Ed Hancock \\ Mountain Energy Partnership \\ Boulder, CO
}

\author{
Greg Barker \\ Mountain Energy Partnership \\ Boulder, $\mathrm{CO}$
}

\author{
Paul Reeves \\ Partnership for Resource Conservation \\ Boulder, CO
}

\begin{abstract}
The authors evaluated a Zero Energy Home (ZEH) built by Ideal Homes in Edmond, Oklahoma, that included an extensive package of energy-efficient technologies and a photovoltaic (PV) array for site electricity generation. The ZEH was part of a Building America (BA) research project in partnership with the Building Science Consortium to exhibit high efficiency technologies while keeping costs within the reach of average home buyers, and was a modified version of a production $1584-\mathrm{ft}^{2}$, three-bedroom, single-story, slab-ongrade design with attached garage. The home included a tight, well-insulated envelope, an energy recovery ventilator, highperformance windows, tankless gas water heater, efficient lights and appliances, and a ground source heat pump (GSHP). We conducted a series of short-term tests beginning in August 2005, and have collected long-term data under occupied conditions since February 2006. The GSHP performance was disappointing until the outdoor unit was replaced, after which time the efficiency began to meet expectations. However, the electricity use of the replacement unit was higher than expected because of an unusually low cooling setpoint. Based on the measured test results, the predicted whole-house energy savings compared to the BA Benchmark was $96 \%$, with savings of $55 \%$ for efficiency measures alone.
\end{abstract}

\section{NOMENCLATURE}

$\mathrm{h}_{\text {conv }}$ convection heat transfer coefficient $\left(\mathrm{W} / \mathrm{m}^{2}-\mathrm{K}\right)$

$\mathrm{h}_{\mathrm{r}}$ linearized radiation heat transfer coefficient $=$ $\sigma \varepsilon\left(\mathrm{T}_{\mathrm{m}}+\mathrm{T}_{\text {sky }}\right)\left(\mathrm{T}_{\mathrm{m}}{ }^{2}+\mathrm{T}_{\text {sky }}{ }^{2}\right)\left(\mathrm{W} / \mathrm{m}^{2}-\mathrm{K}\right)$

$\mathrm{I}_{\mathrm{c}} \quad$ incident solar radiation $\left(\mathrm{W} / \mathrm{m}^{2}\right)$

$\mathrm{i}_{\mathrm{mp}} \quad$ current at maximum power point (A)

$\mathrm{i}_{\mathrm{sc}} \quad$ short circuit current (A)

$\mathrm{P}_{\mathrm{mp}} \quad$ power at maximum power point (W)

$\mathrm{P}_{\mathrm{pv}} \quad$ DC power produced by $\mathrm{PV}(\mathrm{W})$

$\mathrm{P}_{\mathrm{ac}} \quad$ AC power out of the inverter (W)
$\mathrm{T}_{\mathrm{amb}}$ ambient air temperature $(\mathrm{K})$.

$\mathrm{T}_{\mathrm{db}} \quad$ dry-bulb air temperature $\left({ }^{\circ} \mathrm{C}\right)$

$\mathrm{T}_{\mathrm{m}} \quad$ module temperature $(\mathrm{K})$

$\mathrm{T}_{\text {sky }} \quad$ black-body sky temperature $(\mathrm{K})$

$\mathrm{V}_{\mathrm{mp}} \quad$ voltage at maximum power point (V)

$\mathrm{V}_{\mathrm{oc}}$ open circuit voltage $(\mathrm{V})$

$\varepsilon \quad$ emissivity of glazing

$\eta_{0} \quad$ efficiency at Standard Test Conditions

$\eta_{\mathrm{mp}} \quad$ efficiency at maximum power point

$\sigma \quad$ Stefan-Boltzmann constant $\left(\mathrm{W} / \mathrm{m}^{2}-\mathrm{K}^{4}\right)$

$\tau \alpha \quad$ transmittance-absorptance product of glazing and cells

\section{INTRODUCTION}

Ideal Homes built a Zero Energy Home (ZEH) in Edmond, Oklahoma, (a suburb of Oklahoma City) using a comprehensive package of energy efficiency measures and a photovoltaic array to generate electricity on-site. The ZEH was a research project designed to showcase high efficiency technologies, while trying to keep costs reasonable, with the objective of helping to put Zero Energy Homes within the reach of average home buyers. Designed in partnership with Building Science Consortium (BSC), one of seven Building America (BA) industry teams, the $\mathrm{ZEH}$ was a modified version of Ideal Homes Plan 1644, and was a $1584-\mathrm{ft}^{2}$, threebedroom, single-story, slab-on-grade design with attached garage. The home was designed to have a tight, well-insulated envelope, and included an energy recovery ventilator (ERV), high-performance windows, tankless gas water heater, efficient lights and appliances, and a closed-loop ground source heat pump (GSHP) for space conditioning. A photo of the $\mathrm{ZEH}$ is shown in Fig. 1. Key design specifications are listed in Table 1. The overall reduction in energy use was initially expected to be $88 \%$ compared to the BA Benchmark [1] based on preliminary analysis conducted by BSC. 
This report summarizes the results of short-term and longterm testing and analysis of the ZEH. The National Renewable Energy Laboratory (NREL) and BSC performed the initial field testing in August 2005, and NREL visited the site three additional times (November 2005, January 2006, and September 2006) to evaluate subsequent modifications to the house, many of which addressed problems identified during the initial test.

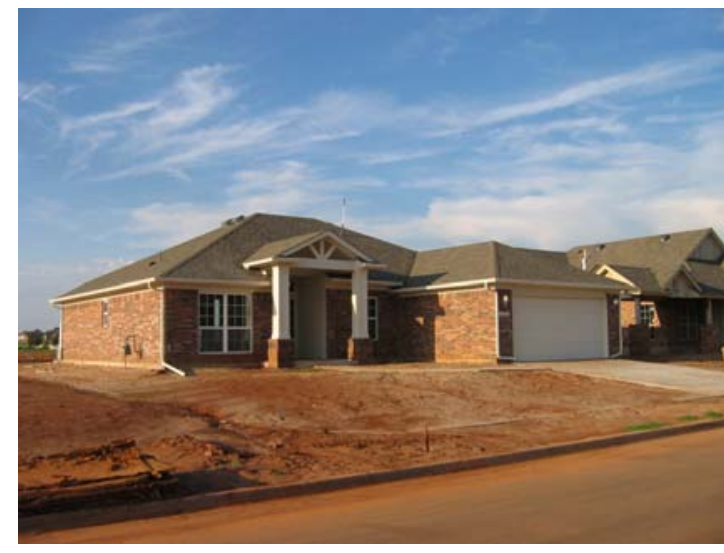

Fig. 1 Ideal Homes ZEH (view from northeast)

Table 1 Key Specifications for Ideal Homes ZEH

\begin{tabular}{|c|c|}
\hline & Ideal Zero Energy Home \\
\hline \multicolumn{2}{|l|}{ Building envelope } \\
\hline Orientation & North \\
\hline Ceiling & R-38 blown cellulose at ceiling \\
\hline Walls & $\begin{array}{l}\text { R-19 blown cellulose }+ \\
\text { R-3 insulating sheathing }\end{array}$ \\
\hline Foundation & Slab, R-4 perimeter insulation \\
\hline Windows & $\begin{array}{l}\text { Double-glazed vinyl-frame LowE } \\
\qquad U=0.39, \mathrm{SHGC}=0.31 \\
\text { Mostly south-facing with overhang }\end{array}$ \\
\hline Infiltration & $\begin{array}{c}\text { 2.5-in }{ }^{2} \text { leakage area per } 100 \mathrm{ft}^{2} \text { envelope } \\
\text { area }\end{array}$ \\
\hline \multicolumn{2}{|l|}{ Mechanical systems } \\
\hline Space heating & $\begin{array}{c}\text { 4.3 COP GSHP, 2-3 ton capacity (original) } \\
\text { 3.5 COP GSHP, 2-ton capacity (final) }\end{array}$ \\
\hline Cooling & $\begin{array}{c}20 \text { EER GSHP, 2-3 ton capacity (original), } \\
\text { 16.6 EER GSHP, 2-ton capacity (final) }\end{array}$ \\
\hline Domestic hot water (DHW) & $\begin{array}{c}\text { Rinnai tankless gas water heater, } 0.82 \\
\text { Energy Factor }\end{array}$ \\
\hline Air-handler location & In conditioned space (utility room) \\
\hline Ducts & $\begin{array}{l}\text { In vented attic, R- } 6 \text { insulation, } \\
5 \% \text { or less leakage to the outside }\end{array}$ \\
\hline Ventilation & $\begin{array}{c}\text { ERV with } 70 \% \text { sensible recovery, } \\
92 \text { cfm @ } 50 \% \text { duty cycle, AirCycler for } \\
\text { mixing only ( } 17 \% \text { duty cycle })\end{array}$ \\
\hline Lighting & $90 \%$ compact fluorescent lighting \\
\hline $\begin{array}{l}\text { Appliances and } \\
\text { miscellaneous electric loads }\end{array}$ & $\begin{array}{c}\text { ENERGY STAR refrigerator, clothes } \\
\text { washer, dishwasher }\end{array}$ \\
\hline PV System & $\begin{array}{l}\text { 5.3-kW DC maximum under standard test } \\
\text { conditions, } 5.1-\mathrm{kW} \text { inverter }\end{array}$ \\
\hline
\end{tabular}

\section{SHORT-TERM FIELD-TEST RESULTS}

Blower Door, Duct Blaster, and Airflow Measurements

All envelope and duct leakage targets were met (Table 2). Even though the ducts were located in an unconditioned attic, air leakage to the outside was only about $3 \%$ of total flow. The measurements indicated that none of the return-air leakage was to the outside, suggesting that the leakage points were either around the perimeter of the registers or near the air handler, which was located in an interior closet.

The overall supply volume $(>1200 \mathrm{cfm})$ was very high for such an energy efficient house. The air handler fan was sized for 3-ton operation of the GSHP in anticipation of large heat loads during the local Parade of Homes. A new fan with an electronically commutated motor (ECM) was installed in September 2005, and the total flow rate was reduced to 800 cfm while the GSHP was operating at 2-ton capacity, which was the vast majority of the time. The ERV and all exhaust fan airflows met design expectations.

Table 2 Blower Door and Duct Blaster Measurements

\begin{tabular}{|l|l|c|c|}
\hline & & Target & Measured \\
\hline \multirow{2}{*}{$\begin{array}{l}\text { Blower } \\
\text { Door }\end{array}$} & cfm@50Pascal & 1230 & 1071 \\
\cline { 2 - 4 } Duct & Effective leakage area $\left(\mathrm{in}^{2}\right)$ & 67.5 & 44.1 \\
\hline \multirow{3}{*}{ Blaster } & cfm@25Pa, total & - & 120 \\
\cline { 2 - 4 } & cfm@25Pa, outside & 60 & 40 \\
\cline { 2 - 4 } & cfm@25Pa, total, supply & - & 87 \\
\cline { 2 - 4 } & cfm@25Pa, outside, supply & - & 40 \\
\hline
\end{tabular}

\section{Tracer-Gas Testing}

The NREL tracer-gas monitoring system was installed in the $\mathrm{ZEH}$ for two nights of testing beginning Friday, August 26. This system monitors the decrease in concentration of sulfur hexafluoride $\left(\mathrm{SF}_{6}\right)$ over time and calculates the overall air-exchange rate of the house in units of air changes per hour $(\mathrm{ACH})$. Six sampling points were used during the test, and small fans were used to maintain uniform mixing throughout the house. Peak temperatures during the afternoon were about $93^{\circ} \mathrm{F}\left(34^{\circ} \mathrm{C}\right)$, with overnight lows of about $66^{\circ} \mathrm{F}\left(19^{\circ} \mathrm{C}\right)$. Although it was quite breezy on Saturday afternoon, the wind died down substantially at night. The results of the tracer-gas test are plotted in Fig. 2.

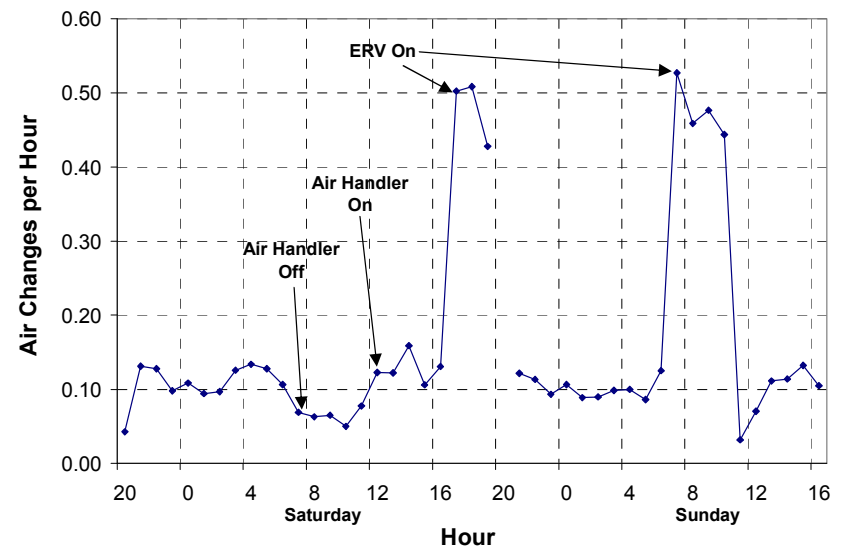

Fig. 2 Tracer-gas results for Ideal Homes ZEH 
Under normal operation, the air infiltration for the ZEH was approximately $0.10-0.15 \mathrm{ACH}$. When the air handler was turned off in the ZEH early Saturday morning (known as a "bump test"), the air-exchange rate decreased by about 0.04 $\mathrm{ACH}$, corresponding to a net effect of approximately $10 \mathrm{cfm}$ caused by duct leakage or room pressurization. Because there was a significant increase in wind speed coincident with the second bump test at noon on Saturday, the result of that test was not meaningful. Each of the two ERV bump tests caused an increase in air-exchange rate of about $0.38 \mathrm{ACH}(94 \mathrm{cfm})$. Because a ventilation rate of $46 \mathrm{cfm}$ was recommended by ASHRAE Standard 62.2, the builder programmed the ERV to operate at a duty cycle of $50 \%$.

\section{Supplemental Duct-Leakage Testing}

A series of alternative duct-leakage tests were conducted as part of an effort to identify appropriate test procedures for evaluating ducts in unconditioned space. The following discussion provides a basic description of the methodology for each test, identifies some of the practical issues encountered during the execution of the test, and analyzes the measured results (Table 3 ).

\section{Table 3 Results of Alternative Duct-Leakage Test} Procedures

\begin{tabular}{|c|c|c|c|c|c|c|}
\hline & 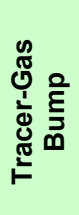 & 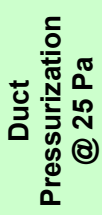 & 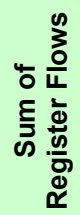 & 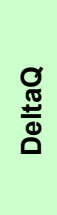 & $\frac{\text { D }}{\stackrel{\text { 至 }}{\mathbf{z}}}$ & 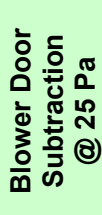 \\
\hline $\begin{array}{l}\text { Total Leakage } \\
(\mathrm{cfm})\end{array}$ & & 120 & & & & \\
\hline $\begin{array}{l}\text { Total Supply } \\
\text { Leakage (cfm) }\end{array}$ & & 87 & 50 & & & \\
\hline $\begin{array}{l}\text { Total Return } \\
\text { Leakage }(\mathrm{cfm})\end{array}$ & & 28 & & & & \\
\hline $\begin{array}{l}\text { Total Leakage to } \\
\text { Outside (cfm) }\end{array}$ & & 40 & & & & -14 \\
\hline $\begin{array}{l}\text { Supply Leakage } \\
\text { to Outside (cfm) }\end{array}$ & & 40 & & -11 & 14 & \\
\hline $\begin{array}{l}\text { Return Leakage } \\
\text { to Outside (cfm) }\end{array}$ & & 0 & & -18 & 0 & \\
\hline $\begin{array}{l}\text { Net Impact on } \\
\text { Infiltration (cfm) }\end{array}$ & 10 & & & & & \\
\hline
\end{tabular}

Tracer-Gas Bump Test. A tracer-gas bump test involves the measurement of whole-house air-change rate immediately before and after a building system is turned on or off. Bump tests are used most frequently to evaluate the whole-house effect of either air-handler or ventilation system operation (or both at once). In order to minimize the complication of wind effects, the test is usually conducted very early in the morning (4 a.m. to 5 a.m.) when winds tend to be the calmest.

A tracer-gas bump test measures the combined effect of duct leakage to the outside and induced infiltration through the building envelope caused by unbalanced duct leakage or room pressurization. It does not measure the actual air leakage through the ducts, and does not provide any information about the split between supply- and return-duct leakage. When ducts are located in a buffer space, such as an attic or crawlspace, the bump test accounts for the supply-duct leakage that reenters the house through return-duct leaks (usually a very small fraction in a well-vented space), but does not provide information about the temperature change of that air.

For the $\mathrm{ZEH}$, the bump test produced a change in infiltration of approximately $0.04 \mathrm{ACH}$ or $10 \mathrm{cfm}$. Because ventilation in the $\mathrm{ZEH}$ was provided by a separate system and the air handler was in conditioned space, this measurement included only the effects of duct leakage to the outside and room pressurization. Although the signal was small, the noise was also small because the envelope was extremely tight, allowing us to estimate the change in $\mathrm{ACH}$ with an uncertainty of about $\pm 25 \%$. If this house would have been as leaky as a more typical house $(\sim 0.35 \mathrm{ACH})$, a small change of $0.04 \mathrm{ACH}$ would have been much more difficult to observe.

Duct Pressurization. A duct-pressurization test typically involves the use of a duct blaster to measure the flow rate of air necessary to pressurize the air-distribution system to $25 \mathrm{~Pa}$. The test is usually performed once with the house depressurized and again with the house pressurized. The latter test allows the isolation of duct leakage lost to the outside. During these tests, the supply and return registers are taped off, and a barrier may be placed in the filter slot to isolate the supply ducts from the return ducts and air handler. This is by far the most common duct-leakage test and is a standard procedure for many residential energy efficiency programs.

Duct-pressurization testing measures the air leakage under uniform pressure conditions, which may be significantly different from the actual pressure conditions when the air handler is operating. The pressure drop across a leak can have a very large effect on the flow rate through that leak. This makes the duct-pressurization test useful as a quality control tool, but not meaningful from the standpoint of quantifying actual duct leakage and associated energy losses under normal operation (unless the measured leakage is zero).

For the ZEH, the supply-duct leakage to the outside at 25 $\mathrm{Pa}$ was $40 \mathrm{cfm}$, and there was no measurable return-duct leakage to the outside. Duct leakage to the inside was about 80 $\mathrm{cfm}$, of which about $47 \mathrm{cfm}$ was on the supply side.

Sum of Register Flows. This method for calculating duct leakage compares the sum of the individual supply-register flows to the total air-handler flow. A similar test is performed by summing the return-register flows. For a house with no duct leakage, these three values should be identical. If the sum of the supply-register flows and the total air-handler flow are not the same, the difference is equal to the total supply-duct leakage. Similarly, the difference between the sum of return air flows and the air-handler flow is equal to the return-duct leakage. Unfortunately, it is not possible to differentiate between leakage to the inside and leakage to the outside using this approach.

The supply-register flow measurements for the ZEH summed to $1250 \mathrm{cfm}$. Because there was no filter slot located at the air handler, the total air-handler flow rate was measured using the duct blaster instead of a calibrated orifice plate. The total flow rate was estimated to be about $1300 \pm 50 \mathrm{cfm}$, 
because the duct blaster reached its maximum capacity at 1250 cfm, and we were just shy of the flow rate necessary to match the pressure in the supply plenum under normal operation. Taking the difference between total flow rate and the sum of supply-register flows, we estimated a supply-duct leakage of approximately $50 \mathrm{cfm}$ using this test approach. Return-duct leakage could be estimated in a similar manner, but the return registers were too large for our flow hood to accommodate. Fortunately, we already knew from the duct-blaster test that the return leakage to the outside was near zero.

One of the concerns with this approach is the accuracy and bias of the flow-hood measurements. Tests conducted by Lawrence Berkeley National Laboratory (LBNL) have suggested that standard flow hoods, such as the one used in this test, have root mean square (RMS) errors in the range of 20\%-30\% for individual measurements [2]. When summing multiple registers, the errors may not average out because of possible bias in the measurements. Combining these potential errors with the difficulties we encountered when measuring total air-handler flow, we expect that our estimate of $50 \mathrm{cfm}$ supply duct leakage is highly uncertain.

DeltaQ. The DeltaQ test is a technique developed by LBNL that examines the change in whole-house $\mathrm{ACH}$ caused by operation of the air-handler fan with the house at different levels of pressurization and de-pressurization [3]. The DeltaQ equation includes four unknown values, including supply- and return-duct leakage and the effective leakage pressures in the supply and return ducts. If the DeltaQ test is run at enough pressures, these unknowns can be calculated with reasonable accuracy using statistical techniques. This approach has several appealing features: (1) The test can be conducted using a standard blower-door set-up; (2) supply and return leakage are calculated separately; and (3) the results represent leakage under normal operating conditions.

NREL conducted a DeltaQ test at the ZEH on Saturday, August 27. The process was straightforward, but relatively time consuming (taking approximately an hour to complete the test). Our understanding is that LBNL is working with the Energy Conservatory to develop an automated system that performs the DeltaQ test at hundreds of pressures in a very short period of time.

The results were difficult to interpret because the leakage values calculated by the DeltaQ spreadsheet were negative, which of course is physically impossible. This was likely a result of the combination of small duct leakage and relatively high winds that caused fluctuations in our outside pressure readings (which were actually measured in the garage with the garage door open slightly).

Nulling Test. The nulling test procedure was developed by Ecotope [4] and uses a blower door to counteract the change in house pressure caused by air handler operation, while measuring the flow rate necessary to offset that pressure change. The blower-door flow rate should be approximately equal to the unbalanced duct leakage, with a net inflow of air from the blower door representing supply-dominated duct leakage and a net outflow indicating return-dominated leakage. The test can be repeated with the return ducts isolated from the air-distribution system (using a barrier in the filter slot and a duct blaster to provide a leak-free return path) in order to measure supply leakage only.

The nulling test is relatively quick and simple to perform and provides a measurement of duct leakage to the outside under normal operating conditions. One limitation with this procedure is caused by the need to isolate a small quantity (duct leakage to the outside) from a much larger effect (envelope leakage).

The nulling test was performed at the ZEH on August 27. Because we already knew that return leakage was negligible, we assumed that the measurement of unbalanced duct leakage would be the same as the supply leakage to the outside. Unfortunately, the interior and exterior pressures fluctuated greatly because of wind effects during the test period (even after the outside pressure tap was moved to the garage), making it very difficult to quantify the change in pressure caused by the operation of the air handler. Using extended time averages, we were eventually able to estimate a reduction in pressure of about $0.1 \mathrm{~Pa}$ when the air handler was turned on, and that a blower door flow rate of $14 \mathrm{cfm}$ seemed to offset that pressure change. This value was fairly consistent with the $10 \mathrm{cfm}$ net leakage measured with the tracer gas.

Blower-Door Subtraction. This is a simple test where a blower-door test is performed at $25 \mathrm{~Pa}$ with and without the supply and return registers taped off. It measures an effect similar to a duct blaster, but with the added complication that duct leakage must be separated from envelope leakage. This test was performed on the $\mathrm{ZEH}$, and the blower-door flow rate measured at $25 \mathrm{~Pa}$ actually decreased from $614 \mathrm{cfm}$ to 600 cfm when the registers were untaped. Similar to our experience with the DeltaQ test on the $\mathrm{ZEH}$, the blower-door subtraction test was complicated by strong wind effects, ultimately yielding meaningless results.

\section{Ground Source Heat Pump (GSHP)}

The GSHP at the ZEH was a customized split-system design with three $200-\mathrm{ft}$ ground wells, somewhat different from the more common packaged systems for which published performance data were available. We conducted field measurements on August 29, 2005, to determine if the GSHP was performing as expected under hot summer conditions. The test data was collected when the outside air and ground loop temperatures were each about $90^{\circ} \mathrm{F}$. We did not measure the ground temperature itself, but we estimate that it was about $73^{\circ} \mathrm{F}$ during the test period at a depth of $4 \mathrm{ft}$, approaching $60^{\circ} \mathrm{F}$ at greater depths. Of course, heat dissipation caused by the operation of the GSHP would have introduced localized shortterm and long-term increases in ground temperature. The field measurements indicated that the energy efficiency ratio (EER) of the GSHP was 8.9 during the test period, significantly lower than the catalog value of about 13 EER with $90^{\circ} \mathrm{F}$ entering water temperature, and much lower than the rated value of about 17 EER under standard test conditions. The heat load for this calculation was approximated using air temperature measurements on each side of the cooling coil, along with an assumed latent heat load equal to $15 \%$ of the sensible heat load.

In the months after learning of these results, engineers from the GSHP manufacturer met with NREL and made some 
changes to the system in an effort to improve the performance. The ground loop was emptied and re-charged to $60 \mathrm{psi}$ when it was observed that the loop was not properly pressurized and there was some debris in the loop. One of the refrigerant filters was removed, and the refrigerant loop was re-charged. In addition, the 1200-cfm air-handler fan was replaced with a blower with an electronically commutated motor (ECM) that operated between 450 and $1200 \mathrm{cfm}$.

There were some concerns raised by the manufacturer regarding the electricity uses that should be included in the calculation of EER and Coefficient of Performance (COP). According to ASHRAE/ISO 13256-1 (the test standard governing the calculation of COP for water-source heat pumps), the "effective power input" used in the calculation of COP should include the compressor, the water pump, the airhandler fan, and all associated controls. However, fan power used in the calculation of COP/EER does not include flow resistance from ducts, and pump power does not include the resistance of the ground loop, because the ultimate designs of these external flow paths would be unknown to the manufacturer. Except for the ISO rating, pump power is generally not included in catalog data for the GSHP industry. As a result, we need to separately evaluate whether the GSHP is performing as designed (published COP without pump power), and as expected by the builder and potential homebuyers (COP including actual pump and fan power, under actual operating conditions).

In January 2006, we measured the air flow rates and power draws corresponding to different fan speeds for the new ECM air handler. The resulting heating COP based on air-side measurements of heat load calculated at 1-hour intervals over a 5-day period beginning in late January 2006 is shown in Fig. 3. A variety of outdoor conditions were encountered during this time period: the outdoor temperature ranged from 36$68^{\circ} \mathrm{F}$, the indoor temperature was about $72^{\circ} \mathrm{F}$, and the ground loop return temperature was in the range of $54-64^{\circ} \mathrm{F}$ while the GSHP was operating.

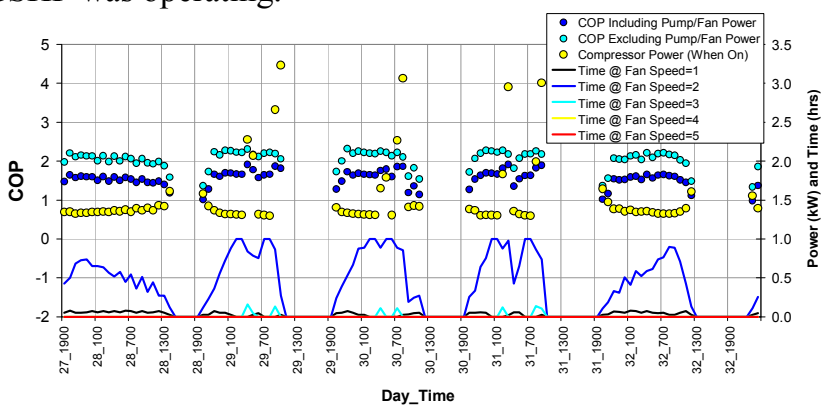

Fig. 3 GSHP coefficient of performance (COP), fan speed, and compressor power following the third site visit in January 2006

The COP is plotted in two ways, both including and excluding the pump power $(240 \mathrm{~W})$ and air handler fan power (146 W for fan speed \#2). Regardless of whether pump and fan power were included, the heating COP continued to be much closer to 2.0 than the value of 4.0 under rated conditions that was published in the manufacturer's catalog.

The outdoor unit, including the compressor, pump, and controls, was replaced by the manufacturer in July 2006 with a unit that was tested in the laboratory under conditions similar to those encountered in the ZEH. In addition, the multi-speed ECM blower was replaced with a single-speed, $700 \mathrm{cfm}$ blower. The replacement GSHP had a more efficient pump $(179 \mathrm{~W})$, and a rated COP of 4.9 in cooling mode. The new outdoor unit and air handler produced a marked improvement in COP. A malfunctioning compressor in the original outdoor unit was later identified by the manufacturer as the reason for the poor performance.

The installed COP of the new GSHP system was evaluated using three different types of sensors to calculate the heating and cooling load. Two types of sensors were installed in the ground water loop: resistance temperature detectors (RTDs) and thermopiles. Additionally, a pair of thermocouples measured the air temperatures in the supply and return plenums. The measured compressor and pump power were subtracted from the heat transfer rate to the ground-water when calculating the useful cooling load and added when calculating the heating load.

The GSHP efficiency as a function of duty cycle is plotted in Fig. 4, with positive COP in cooling mode and negative in heating mode. The values are actually quite different using the different sensors, but on balance we have the highest confidence in the water-side RTD because the installed locations of the thermopiles are sub-optimal, and the air-side readings are complicated by greater measurement uncertainties. However, there are certain system losses accounted for by the air-side measurements that are not captured by the water-side measurements, such as energy losses from the refrigerant lines to the unconditioned attic, an effect estimated to be less than $5 \%$ by the GSHP manufacturer. Duct leakage to the attic is also not reflected in the water-side calculations, though we estimate this effect to be less than $1 \%$.

It is evident from Fig. 4 that larger differences between air-side and water-side COP calculations were present in heating mode compared to cooling mode. The data doesn't provide a clear explanation, but the cause of this trend may be either inaccurate average air temperature measurements caused by temperature non-uniformity over the cross-section of the ducts, or inaccurate flow rates caused by a change to system operation over time. We also examined the effects of heat losses from the pump and compressor to the outside, and thermodynamic differences in density and velocity before and after the air handler, and we feel confident that neither effect can explain the larger discrepancy between the air-side and water-side COP in heating mode compared to cooling mode.

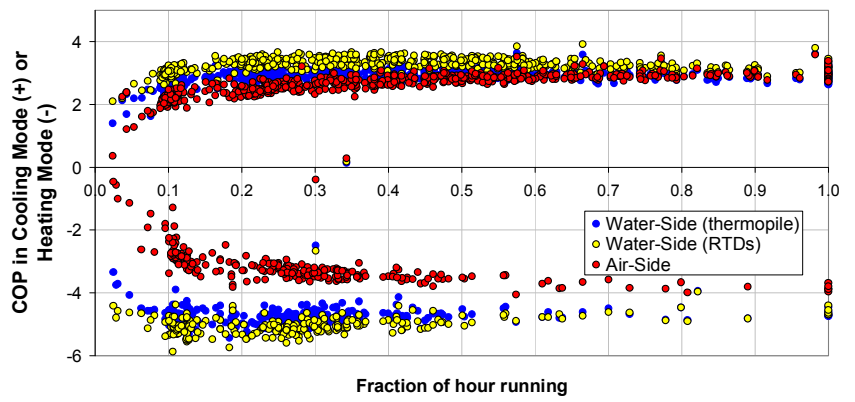

Fig. 4 Installed COP (including pump and fan energy) of the GSHP using alternative temperature measurements to calculate useful heat load 
Figs. 5 and 6 compare the COP of the replacement GSHP (not including pump power) in both heating and cooling mode with laboratory data measured by the manufacturer using various ground-water and conditioned-air temperatures $\left(\mathrm{T}_{\mathrm{db}}\right)$. The results match very well, indicating that the GSHP performance is now consistent with the manufacturer's expectations.

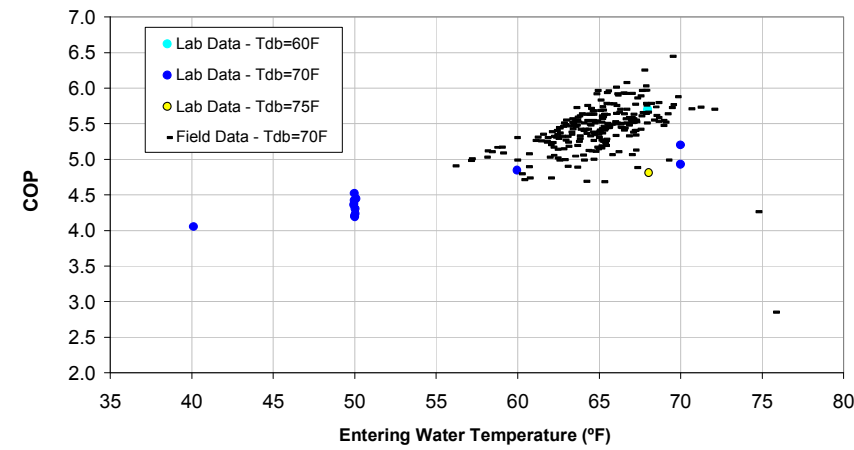

Fig. 5 Installed vs laboratory COP of the GSHP in heating mode following replacement of the outdoor unit in July 2006

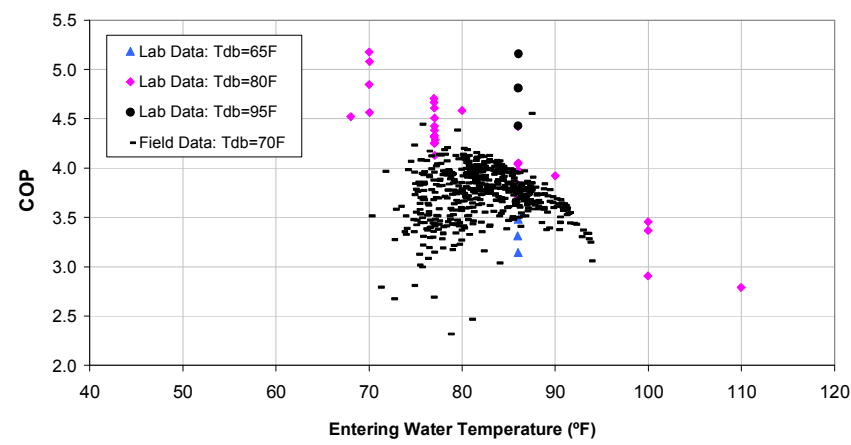

Fig. 6 Installed vs laboratory COP of the GSHP in cooling mode following replacement of the outdoor unit in July 2006

\section{Photovoltaic System}

On August 28-29, 2005, NREL recorded 10-min averaged measurements of the PV system installed on the roof of the ZEH. During the 2-day test, measurements were made of the alternating current (AC) power delivered by the inverter, the solar radiation in the plane of the array, and the back-ofmodule temperature $\left(\mathrm{T}_{\mathrm{pv}}\right)$. Using $\mathrm{T}_{\mathrm{pv}}$ as a surrogate for cell temperature, the manufacturer's performance parameters and model were used to calculate the "expected" DC power output of the array under the actual weather conditions. The measured efficiency was about $22 \%$ lower than expected. During the second site-visit in late November 2005, NREL noted that one of the seven photovoltaic strings was not connected to the inverter, which explained most of the $22 \%$ difference. The problem was corrected by the PV installer in mid-December 2005.

NREL conducted a total of $328 \mathrm{i}-\mathrm{V}$ (current-voltage) curve measurements [5] over a range of solar and temperature conditions during the third visit to the site in January 2006. These short-term measurements were used to calibrate a TRaNsient SYstems Simulation (TRNSYS) [6] model for predicting long-term performance of the PV system.
Parameters at Standard Test Conditions (STC) calculated for the calibrated model are compared in Table 4 to those provided by the manufacturer. The measured currents and voltages were all within $5.5 \%$ of the values specified by the manufacturer. It is important to remember that the manufacturer's specifications are for a uniform cell temperature of $25^{\circ} \mathrm{C}$, whereas the measured parameters are for a back-of-module temperature of $25^{\circ} \mathrm{C}$. We attempted to place our sensor in an "average" location, but the effective average cell temperature over time may have been higher or lower than our point measurement.

Table 4 Comparison of parameters in January 2006: manufacturer-supplied to measured

\begin{tabular}{lcclc}
\hline Description & Rated & $\begin{array}{c}\text { Measured } \\
\text { (Curve } \\
\text { Traces) }\end{array}$ & Units & $\begin{array}{c}\text { Ratio: } \\
\text { Measured/ } \\
\text { Rated }\end{array}$ \\
\hline $\mathrm{i}_{\mathrm{sc}}$ @STC, Array & 26.25 & 26.09 & amps & 0.994 \\
$\mathrm{~V}_{\mathrm{oc}}$ @STC, Array & 270.00 & 268.42 & volts & 0.994 \\
$\mathrm{i}_{\mathrm{mp}}$ @STC, Array & 24.29 & 25.63 & amps & 1.055 \\
$\mathrm{~V}_{\mathrm{mp}}$ @STC, Array & 219.20 & 212.51 & volts & 0.969 \\
$\mathrm{P}_{\mathrm{mp}}$ @STC, Array & 5324 & 5446 & watts & 1.023 \\
$\eta_{\mathrm{mp}}$ @STC, Array & 16.1 & 16.5 & $\%$ & 1.023
\end{tabular}

\section{ANNUAL ENERGY SIMULATIONS}

\section{Photovoltaic System}

Developing an accurate model for predicting the effective average module temperature of a PV array is perhaps the most difficult task in modeling its annual performance. Fortunately, a single temperature, which may be offset from the average but follows the average temperature, was deemed to be sufficient for our approach. As long as the point temperature measured during the short-term test (i-V traces) can be modeled accurately, the TRNSYS model simply uses this temperature in predicting PV performance. Equation 1 gives the model we employed in this study:

$\mathrm{T}_{\mathrm{m}}=1 /\left(\mathrm{h}_{\mathrm{r}}+\mathrm{h}_{\mathrm{conv}}\right) *\left\{\left[\left((\tau \alpha)-\eta_{0}\right)\right] * \mathrm{I}_{\mathrm{c}}+\left[\mathrm{h}_{\mathrm{r}}\right] * \mathrm{~T}_{\mathrm{sky}}+\mathrm{h}_{\mathrm{conv}} * \mathrm{~T}_{\mathrm{amb}}\right\}$

Equation 1 takes into account convection heat transfer from the module to the ambient air, as well as radiative heat transfer to the sky. It is assumed that radiation from the back of the module to the roof surface (which is only a few inches away) is negligible. We did not have a measurement of wind speed at the site, so for this study we assumed a constant convection heat transfer coefficient $\left(\mathrm{h}_{\text {conv }}\right)$. For our data set, a best-fit to Equation 1 yielded a value of $h_{\text {conv }}=21.5 \mathrm{~W} / \mathrm{m}^{2}-\mathrm{K}$ with an RMS error of $4.2^{\circ} \mathrm{C}$ for the hours where the incident solar radiation was greater than $50 \mathrm{~W} / \mathrm{m}^{2}$.

Figures 7 and 8 illustrate some of the accuracies and deficiencies of the model described by Equation 1. Both days were cloudless days with mid-day ambient air temperatures of between $9^{\circ} \mathrm{C}$ and $13^{\circ} \mathrm{C}$. The model matched the measured array-center temperature quite well for March 13 (Fig. 7) but not very well for March 14 (Fig. 8). The bad fit on March 14 may be a result of different wind conditions (speed and/or direction) or may be caused by an inadequate description of the heat transfer geometry assumed in Equation 1. The reader should also note the light-blue line (square symbols), which 
represents the measured temperature difference between the center module and the corner module. The fact that this difference is not constant illustrates the weakness of assuming that the average module temperature linearly follows any single point temperature measurement of the array. A methodology for accurately predicting the temperature behavior of PV arrays, including the possible application of infrared scanning, is an important topic for further research.

In Fig. 9 we compare the measured direct-current (DC) output of the PV array to several different simulation results on a monthly basis. In all cases, the simulations were driven by measured weather data, but the module temperature was handled in three different ways: (1) using the measuredmodule temperature, (2) using the temperature predicted by Equation 1 fit to 5 months of data, and (3) using the temperature predicted by Equation 1 fit to the 2 days of data during the short-term tests. In addition we show the results based on our TRNSYS model derived from the curve traces, as well as the model based on the manufacturer's specifications and the measured module temperature. The seventh bar is similar to the model used after the initial shortterm test in August 2005. In general, the two advantages of using a model based on measured data are (1) that the model relies on an actual measured module temperature, even if does not represent the average module temperature, and (2) it takes into account the effects of wiring losses and connection resistances, which are difficult to ascertain any other way. In this case, because all of the models predict the PV output fairly well for the 3-month period, it appears that the errors are not very large, or cancel out over an extended time period.

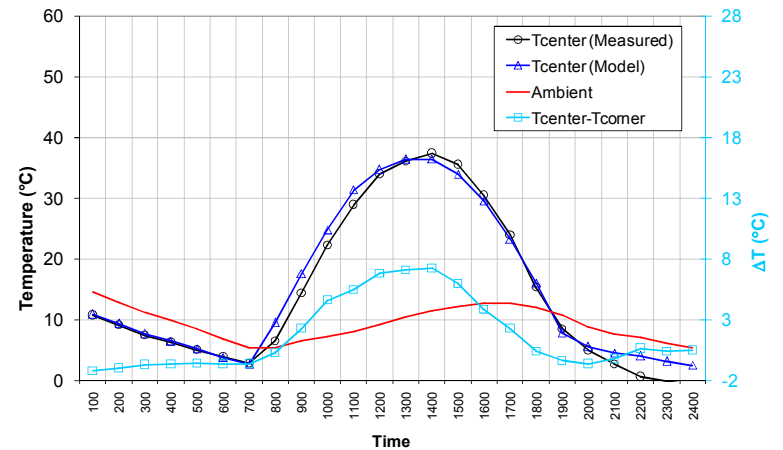

Fig. 7 Measured and predicted center-of-array module temperature, showing a good comparison of measured to modeled.

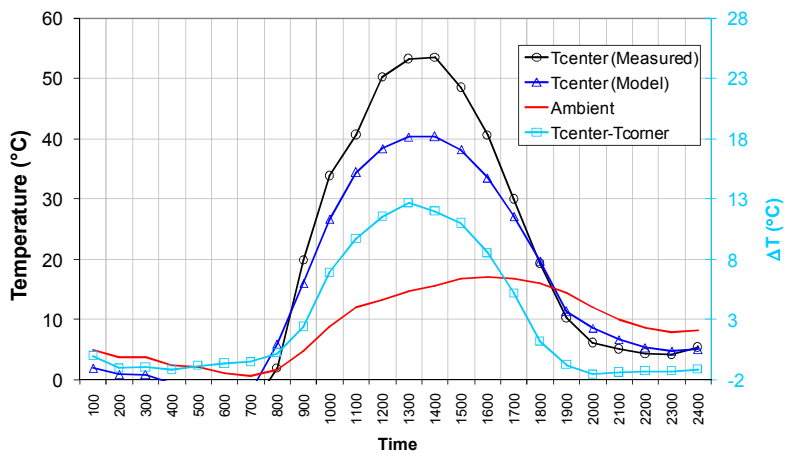

Fig. 8 Measured and predicted center-of-array module temperature, showing a poor comparison of measured to modeled.
TRNSYS was used to simulate the performance of the PV system under TMY2 (Typical Meteorological Year) conditions using the curve fit of module temperature to longterm data (the fourth bar in Fig. 9). The results are summarized in Table 5. The predicted annual site AC electricity generation based on this calibrated model was 9288 $\mathrm{kWh} /$ year.

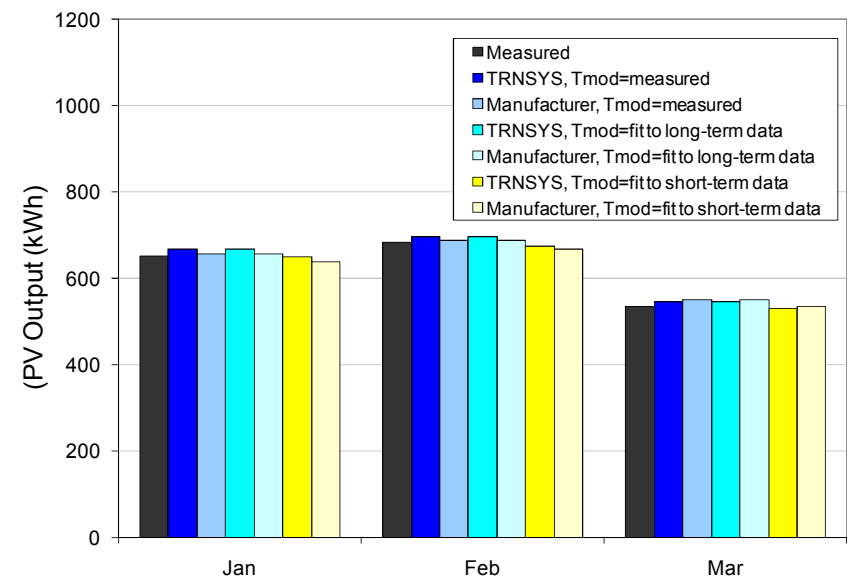

Fig. 9 Monthly DC energy production by the PV array using various modeling approaches

Table 5 Predicted Monthly Performance of the PV System Using TRNSYS and Measured Data

\begin{tabular}{lcccccc}
\hline Month & $\begin{array}{c}\text { Ambient } \\
\text { Temp }\end{array}$ & $\begin{array}{c}\text { Wind } \\
\text { Speed }\end{array}$ & Insolation & $\mathbf{P}_{\mathbf{p v}}$ & $\mathbf{P}_{\mathrm{ac}}$ & $\begin{array}{c}\text { System } \\
\text { Efficiency } \\
(\mathbf{A C})\end{array}$ \\
\hline Jan & $\left({ }^{\circ} \mathrm{C}\right)$ & $(\mathrm{m} / \mathrm{s})$ & $\left(\mathrm{kWh} / \mathrm{m}^{2}\right)$ & $(\mathrm{kWh})$ & $(\mathrm{kWh})$ & \\
Feb & -0.3 & 6.2 & 122 & 676 & 621 & $15.5 \%$ \\
Mar & 3.3 & 4.8 & 130 & 711 & 657 & $15.3 \%$ \\
Apr & 10.4 & 6.7 & 165 & 872 & 807 & $14.8 \%$ \\
May & 14.8 & 6.9 & 182 & 941 & 871 & $14.5 \%$ \\
Jun & 20.6 & 5.9 & 183 & 929 & 853 & $14.2 \%$ \\
Jul & 23.7 & 5.3 & 188 & 945 & 868 & $14.0 \%$ \\
Aug & 26.3 & 5.3 & 201 & 998 & 915 & $13.8 \%$ \\
Sep & 27.9 & 4.6 & 198 & 976 & 896 & $13.7 \%$ \\
Oct & 22.1 & 3.9 & 168 & 854 & 785 & $14.1 \%$ \\
Nov & 16.9 & 4.8 & 164 & 855 & 789 & $14.6 \%$ \\
Dec & 9.8 & 4.7 & 124 & 667 & 612 & $14.9 \%$ \\
YEAR & 5.1 & 5.2 & 122 & 670 & 614 & $15.2 \%$ \\
\hline
\end{tabular}

\section{Whole-House Simulations}

An hourly energy analysis of the ZEH was performed using the DOE-2.2 building-simulation software. The measured performance characteristics of the $\mathrm{ZEH}$ in its final configuration were used as inputs to the model whenever possible. Such inputs included duct leakage, envelope leakage, GSHP efficiency, ventilation rate, fan energy (ERV and air handler), and ERV sensible heat recovery.

In accordance with the Building America Performance Analysis Procedures [7], the ZEH was compared to the BA Benchmark and Builder Standard Practice (BSP). The BSP specifications for Ideal Homes were based on the Eagle Cliff community built to ENERGY STAR standards in Norman, 
Oklahoma, along with information provided by Ideal Homes. Key features of the BSP house include a condensing gas furnace, SEER 14 air conditioner, clear double-pane windows, perimeter slab insulation, tight building envelope and ducts, and a standard gas water heater.

The predicted annual source energy use for the Benchmark and the ZEH are shown in Fig. 10. Source energy, also known as primary energy, is assumed to be 3.16 times site energy for electricity [1], and includes the effects of generation and transmission losses. The corresponding site-tosource energy multiplier for natural gas is 1.06. Space-heating and cooling energy are both dramatically reduced for the ZEH, and significant improvements are made to the DHW and lighting loads. The largest remaining end-use category is "Appliances/MELs," which is the most difficult category for a builder to influence because these loads are primarily under the control of the occupants.

A breakdown of the change in cumulative energy savings associated with individual energy efficiency measures is shown in Table 6. Site energy, source energy (which includes generation and distribution losses for electricity), and energy cost savings are shown for each measure. Total annual source energy savings is projected to be $96 \%$, with $55 \%$ for efficiency measures alone, and the rest attributable to the PV system. Other than the PV system and measures that are already part of Ideal Homes standard practice (which is $35 \%$ more efficient than the Benchmark), the improvements that made the greatest impact were the efficient lighting and appliances, the tankless water heater, improved insulation, and the GSHP. Because Ideal Homes standard practice for space heating is a condensing gas furnace, and natural gas prices are high in Oklahoma, the GSHP measure appears more beneficial on a local energy cost basis (20\% savings) than it does on a source energy basis (4\% savings) when compared to BSP.

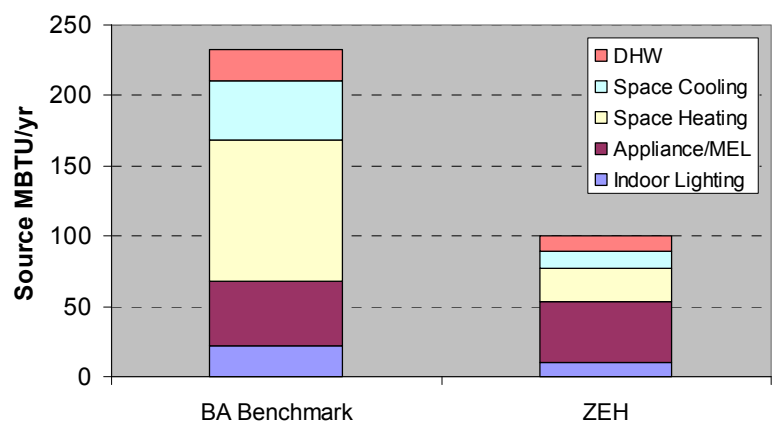

Fig. 10 Predicted annual energy use for the ZEH and Benchmark

Table 6 Predicted Savings for Individual Energy Efficiency Measures in the Ideal Homes ZEH

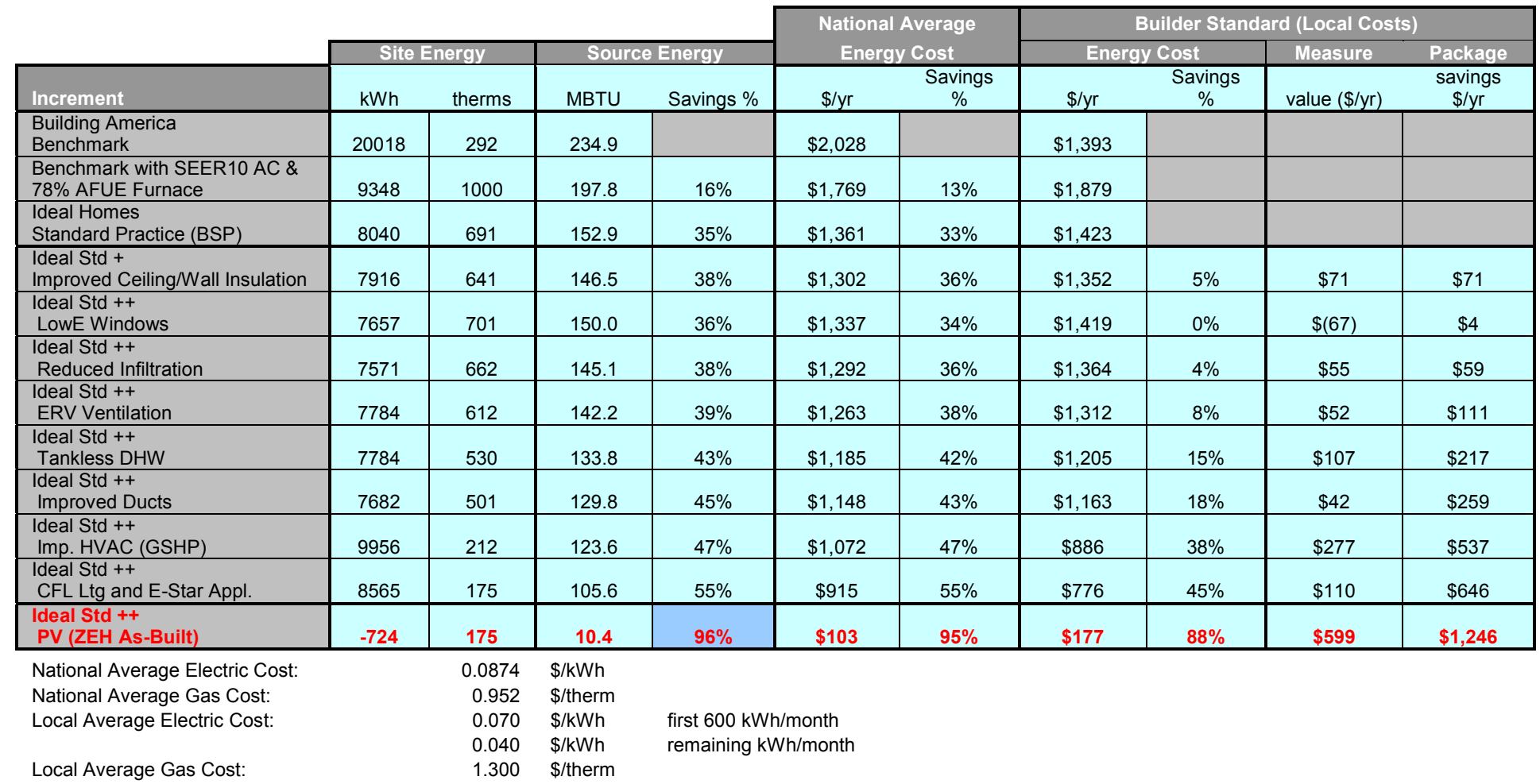

The high-performance windows (low emissivity, low solar heat gain) actually had a negative effect on energy savings compared to the BSP windows (clear double-pane, U $=0.46$, SHGC $=0.57$ ), primarily because the reduction in radiative heat losses associated with the low-emissivity coating $(\mathrm{U}=0.39)$ was outweighed by the reduction in free heating energy associated with low solar heat gain $(\mathrm{SHGC}=$ 0.31 ). Because most of the windows were already located on the south façade, and significant summertime shading was already provided by the roof overhang, there was no energy benefit to the use of low-SHGC glass. However, certain 
comfort-related benefits are associated with low-SHGC glass that must also be considered.

Another somewhat surprising result is the small apparent benefit of the energy recovery ventilator (ERV). However, at that step of the analysis the heating system was an efficient gas furnace consistent with BSP. As a result, the ERV is trading natural gas against electricity on a source-energy basis, making it appear about $33 \%$ less beneficial than it would in conjunction with an electric heat pump. This illustrates the significant impact of alternate sequencing on the predicted energy savings for an individual measure. It should also be noted that the ERV has a larger effect on energy cost, because the local gas rate is very high $(\$ 1.30 /$ therm) near Oklahoma City and the electricity rate is very low $(7 \notin / \mathrm{kWh})$, especially when a household uses more than $600 \mathrm{kWh} / \mathrm{month}(4 \notin / \mathrm{kWh})$.

NREL examined the effect on energy and cost savings for several different space-conditioning systems, including the GSHP system used in the ZEH. We compared this system to the Ideal Homes standard practice $(90 \%$ AFUE furnace and SEER 14 air conditioner), along with a SEER 13 air-source heat pump, which was the National Appliance Energy Conservation Act (NAECA) minimum efficiency for 2006. The source energy use for each system, assuming the Benchmark thermostat settings of $71^{\circ} \mathrm{F}$ for heating and $76^{\circ} \mathrm{F}$ for cooling, is shown in Fig. 11. It appears that the GSHP system uses significantly less source energy than the other options considered. Because the cost of electricity is exceptionally low in Oklahoma compared to natural gas, the energy cost for the GSHP would also be the lowest. However, first cost must also be considered when evaluating costeffectiveness.

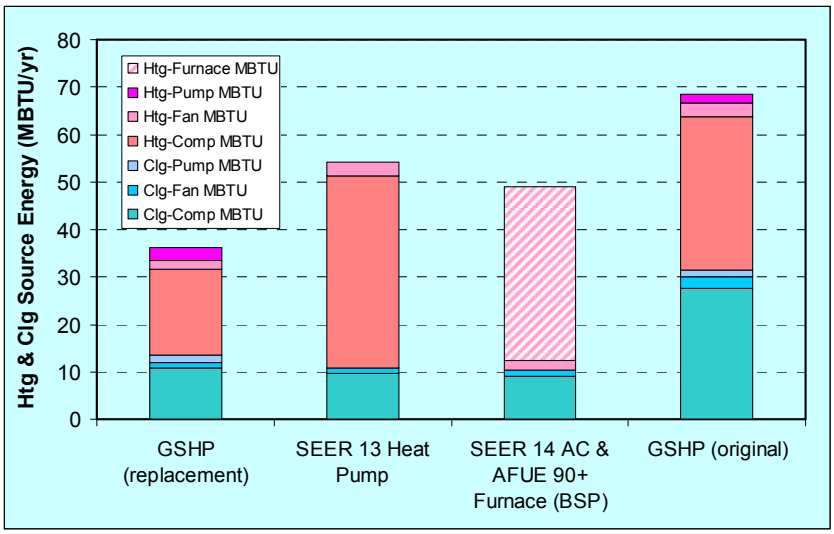

Fig. 11 Heating and cooling source energy with alternative HVAC systems

\section{LONG-TERM MONITORING}

NREL installed long-term monitoring equipment in the ZEH in late November 2005 and began recording the energy use of key building systems under occupied conditions in February 2006. One issue we observed was the diminished COP of the GSHP caused by the very low cooling setpoint of $70^{\circ} \mathrm{F}$ that was being used in the occupied home. The GSHP operated at lower efficiency because the heat transfer rate at the cooling coil was diminished. At the same time, the cooling load was larger because the temperature difference between the inside and outside conditions was larger than usual. Fig. 12 shows the estimated effect of various cooling setpoints on annual cooling energy for the ZEH. By cooling their home to $70^{\circ} \mathrm{F}$, we estimate that the occupants were using 2.5 times more cooling energy than they would have if they had used a more typical setpoint of $76^{\circ} \mathrm{F}$.

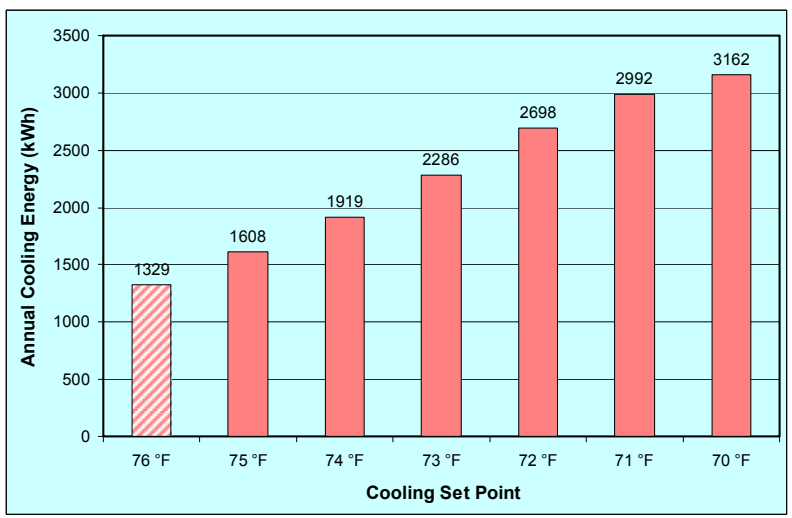

Fig. 12 Impact of cooling thermostat setting on GSHP electricity use

The measured electricity use and PV generation for the first 10 months of occupancy are shown in Fig. 13. Until July, the actual electricity use was much higher than predicted because of the unexpectedly poor performance of the GSHP. After the outdoor unit was replaced in July, there was generally closer similarity between predicted and measured electricity use. PV generation was consistent with expectations, but has met only $64 \%$ of the electricity use for the ZEH, instead of the $100 \%$ predicted. It must be noted that the predicted values for both the GSHP and the PV system were based on typical weather conditions and occupant behavior, so a good correlation is not to be expected until the model is adjusted to match actual operating conditions, which will happen after 1 year of data are collected for the new GSHP system.

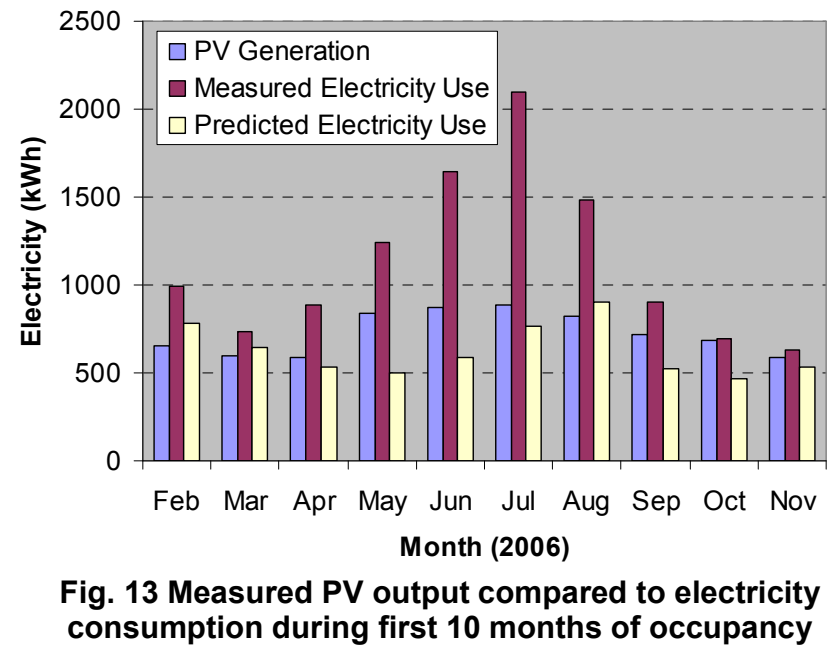

Natural gas usage for DHW for the first 10 months of occupancy is shown in Fig. 14. Actual monthly gas consumption was less than predicted, at least partly because 
the daily volume of hot water was less than expected (29 gal/day compared to 56 gal/day in June and July).

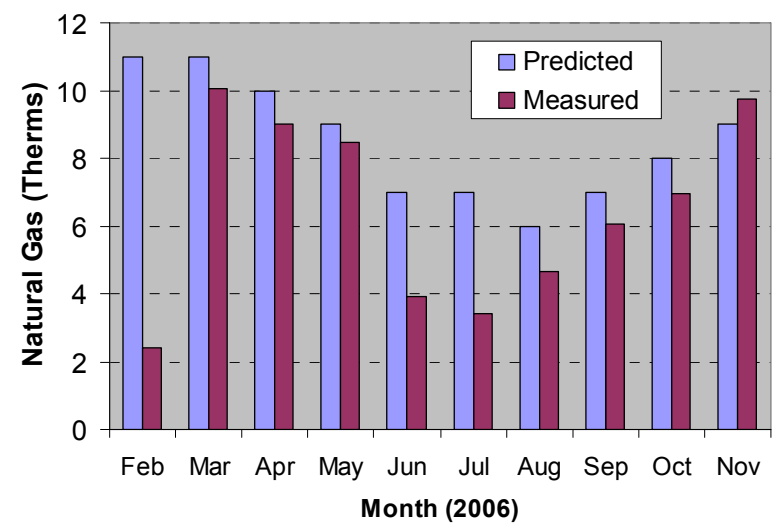

Fig. 14 Measured gas usage for DHW compared to simulation during first 10 months of occupancy

\section{CONCLUSIONS}

The following conclusions summarize the key findings of the field testing and analysis of the Ideal Homes ZEH:

- The envelope and duct leakage targets established by BSC were met for the ZEH, as measured using a blower door and duct blaster.

- Tracer-gas testing verified the tightness of the building envelope. During the test period, the natural infiltration rate was typically less than $0.10 \mathrm{ACH}$. We would expect a somewhat higher natural ACH during the winter when driving forces tend to be larger.

- Tracer-gas bump tests in the ZEH indicated that the increase in whole-house air-exchange rate caused by air handler operation was only about $10 \mathrm{cfm}$ even though the ducts were in an unconditioned attic.

- Each of the six duct-leakage test methods we attempted had different strengths and weaknesses. Based on our results, none of the methods seem to be both simple and accurate. The tracer-gas bump test provides the most accurate information for use in a whole-house simulation tool, but the necessary equipment is quite expensive. The duct-blaster test is probably the best quality control tool in new construction because of its simplicity and ability to disaggregate supply vs. return and outside vs. inside leakage.

- The initial performance of the GSHP was poor compared to the manufacturer's rating because of a defective compressor. Once the outdoor unit was replaced with a new unit that was tested in the laboratory under the same operating conditions as the $\mathrm{ZEH}$, the installed COP matched design expectations.

- The power output of the PV system was initially $22 \%$ less than its rated value, but the system began performing as expected once we discovered that one of seven strings was not connected to the inverter and a repair was made.

- Predicting the average PV array temperature with accuracy was problematic for this project. However, the errors appear to be small enough that our model has predicted overall monthly PV output very well.

- The predicted whole-house energy savings for the ZEH compared to the Building America Benchmark is $96 \%$, exceeding the goal of $88 \%$ established by BSC and Ideal Homes. For efficiency measures alone, the predicted energy savings is $55 \%$. The largest contributors to the energy savings (over and above Ideal Homes standard practice) are the PV system, compact fluorescent lights and ENERGY STAR appliances, improved envelope insulation, the GSHP, and the tankless gas water heater.

- The low solar heat gain windows installed in the ZEH $(\mathrm{U}=0.39, \mathrm{SHGC}=0.31)$ are not expected to save energy compared to the Ideal Homes standard practice windows $(\mathrm{U}=0.46, \mathrm{SHGC}=0.57)$ given the climate and the architectural design of the house.

\section{ACKNOWLEDGMENTS}

The authors express our appreciation to Vernon McKown, Todd Booze, and Tim Sullivan of Ideal Homes for providing NREL with extensive field support, including generous access to the ZEH during the test period. We would also like to acknowledge the assistance of Mark Sevier and the rest of the BSC team for their help in testing the ZEH and for offering their insights throughout the project. The engineering team at ClimateMaster provided valuable feedback on the GSHP testing and analysis. Finally, we want to thank Ed Pollock and George James of DOE for the leadership and resources necessary to perform this work.

\section{REFERENCES}

[1] R. Hendron, 2005, "Building America Research Benchmark Definition, Updated December 29, 2004," NREL Report No. 37529, Golden, CO.

[2] C.P. Wray, I.S. Walker, and M.H. Sherman, 2002, "Accuracy of flow hoods in residential applications," Proceedings of the ACEEE Summer Study on Energy Efficiency in Buildings, Pacific Grove, California, Volume 1, Pages 339-350, LBNL-49697, Washington, DC.

[3] D.J. Dickerhoff, I.S. Walker, and M.H Sherman, 2005, "Validating and Improving the DeltaQ Duct Leakage Test," LBNL 53959, Berkeley, CA.

[4] P.W. Francisco, and L.S. Palmiter, 2001, "The Nulling Test: A New Measurement Technique for Estimating Duct Leakage in Residential Homes," ASHRAE Transactions vol. 107, pt 1, Atlanta, GA.

[5] G. Barker, P. Norton, 2003, "Building America System Performance Test Practices: Part 1 - Photovoltaic Systems," NREL Report No. TP-550-30301, Golden, CO.

[6] S. Klein., et al., 2000, TRNSYS: A Transient System Simulation Program - Reference Manual, Solar Energy Laboratory, University of Wisconsin, Madison, WI.

[7] R. Hendron, R. Anderson, R. Judkoff, C. Christensen, M. Eastment, P. Norton, P. Reeves, and E. Hancock, 2004, "Building America Performance Analysis Procedures: Revision 1,” NREL Report No. TP-55035567, Golden, CO. 


\section{REPORT DOCUMENTATION PAGE}

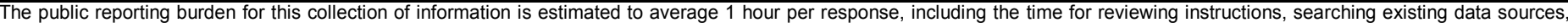

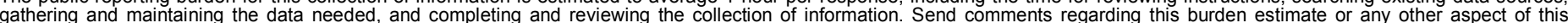

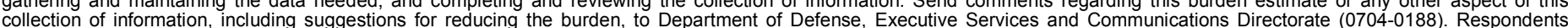

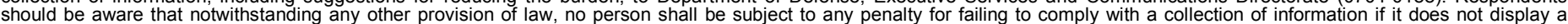

should be aware that notwithstand

PLEASE DO NOT RETURN YOUR FORM TO THE ABOVE ORGANIZATION.

\begin{tabular}{l|l|l|l} 
1. REPORT DATE $(D D-M M-Y Y Y Y)$ & 2. & REPORT TYPE & 3. DATES COVERED (FrOm - TO)
\end{tabular}

August 2008

Conference Paper

4. TITLE AND SUBTITLE

Field Evaluation of a Near Zero Energy Home in Oklahoma

5a. CONTRACT NUMBER

DE-AC36-99-G010337

5b. GRANT NUMBER

5c. PROGRAM ELEMENT NUMBER

6. AUTHOR(S)

R. Hendron, E. Hancock, G. Barker, and P. Reeves

5d. PROJECT NUMBER

NREL/CP-550-40875

5e. TASK NUMBER

BET88004

5f. WORK UNIT NUMBER
7. PERFORMING ORGANIZATION NAME(S) AND ADDRESS(ES)

National Renewable Energy Laboratory

1617 Cole Blvd.

Golden, CO 80401-3393
8. PERFORMING ORGANIZATION REPORT NUMBER

NREL/CP-550-40875

9. SPONSORING/MONITORING AGENCY NAME(S) AND ADDRESS(ES)

10. SPONSOR/MONITOR'S ACRONYM(S) NREL

11. SPONSORING/MONITORING AGENCY REPORT NUMBER

12. DISTRIBUTION AVAILABILITY STATEMENT

National Technical Information Service

U.S. Department of Commerce

5285 Port Royal Road

Springfield, VA 22161

\section{SUPPLEMENTARY NOTES}

14. ABSTRACT (Maximum 200 Words)

The authors evaluated a zero energy home built by Ideal Homes in Edmond, Oklahoma, that included an extensive package of energy-efficient technologies and a photovoltaic array for site electricity generation. The home was part of a Building America research project in partnership with the Building Science Consortium to exhibit high efficiency technologies while keeping costs within the reach of average home buyers.

15. SUBJECT TERMS

photovoltaics; pv; zero energy home; building america

16. SECURITY CLASSIFICATION OF:
\begin{tabular}{|l|l|l|}
\hline $\begin{array}{l}\text { a. REPORT } \\
\text { Unclassified }\end{array}$ & $\begin{array}{c}\text { b. ABSTRACT } \\
\text { Unclassified }\end{array}$ & $\begin{array}{c}\text { c. THIS PAGE } \\
\text { Unclassified }\end{array}$ \\
\hline
\end{tabular}

\begin{tabular}{l|l|} 
17. LIMITATION & 18. \\
OF ABSTRACT & OF PAGES \\
UL & \\
\end{tabular}

19a. NAME OF RESPONSIBLE PERSON

19b. TELEPHONE NUMBER (Include area code) 